\title{
A Peculiar Case of Hanging - A Case Report
}

\author{
Sabyasachi Nath* and H K Pratihari \\ State Forensic Science Laboratory, Tripura, India
}

Submission: March 08, 2018; Published: April 03, 2018

*Corresponding author: Sabyasachi Nath, State Forensic Science Laboratory, Tripura, India; Email: drsabyasachinath@gmail.com

\begin{abstract}
A large number of cases are reported on suicide by hanging in India. But hanging case with tied-hand/or leg along with feet touching the bed/ground is rare. The crime scenes of such cases are very suspicious and doubtful to the investigating officer and public too. Moreover, sufficient literature is also not available to know the criminal profile of the victim in such cases. The observation of undisturbed crime scene in partial suicidal hanging cases with tied-hand and autopsy study are important to establish the suicide/or homicide. In one case, the victim committed suicide on leaning, feet touching the bed and tied-hand position in his bedroom. A suicidal note was also found near the hanging place. The undisturbed crime scene analysis in hanging position, criminal profile along with autopsy study and forensic tests of suicidal note could establish the case of suicidal hanging.
\end{abstract}

Keywords : Suicidal hanging; feet touching the bed; tied-hands; crime scene; criminal profile; autopsy study

Abbreviations : NCRB: National Crime Records Bureau

\section{Introduction}

As per National Crime Records Bureau (NCRB), MHA, Govt. of India, 60,952 persons committed suicide by hanging in the year 2015 and this number contributes about $45.6 \%$ to total suicide cases in India [1]. There are various methods of killing oneself, but suicidal hanging is preferable since it is almost painless. It takes very less time to end life and easy to locate place (indoor/outdoor) as well as commonly available hanging materials like rope, napkin, saree, dupatta, long cloth (dhoti) etc [2]. Further, it is seen that different methods are used by the victims manifesting the following psychological behavior in the process of hanging [3-6].

a) Close the eyes/face with napkin to avoid fear of death,

b) Tie both hands behind by napkin/ handkerchief/towel/belt to prevent self defense,

c) Tie both legs to prevent support from nearby article,

d) Tie with dupatta together in love pact suicide,

e) Tie tag on the wrist showing name, address etc. for easy identity at unknown place,

f) Suicide notes stating nobody/or someone responsible for death,

g) Increase body weight hand tied with bag full of books to enforce constriction,

h) Drugging/hanging together to ensure death,

i) Self inflicted injuries failing by suicidal hanging.
In this case the victim committed partial suicidal hanging in an unusual way with tied hands leaving a suicidal note addressed to the police stating not to frame charge against anybody including wife for his death.

\section{Case Report}

The victim was married having small family with a 4 year old child. He used to maintain the family with poor income from a fast food shop. The economic condition coupled with conjugal relation with wife was not congenial. As a result, victim was suffering from mental agony and was unstable. The suffering further led to depression, resulted in committing suicidal hanging in his bed room bolted from inside. A suicidal note was also found near the hanging place.

\section{Observation}

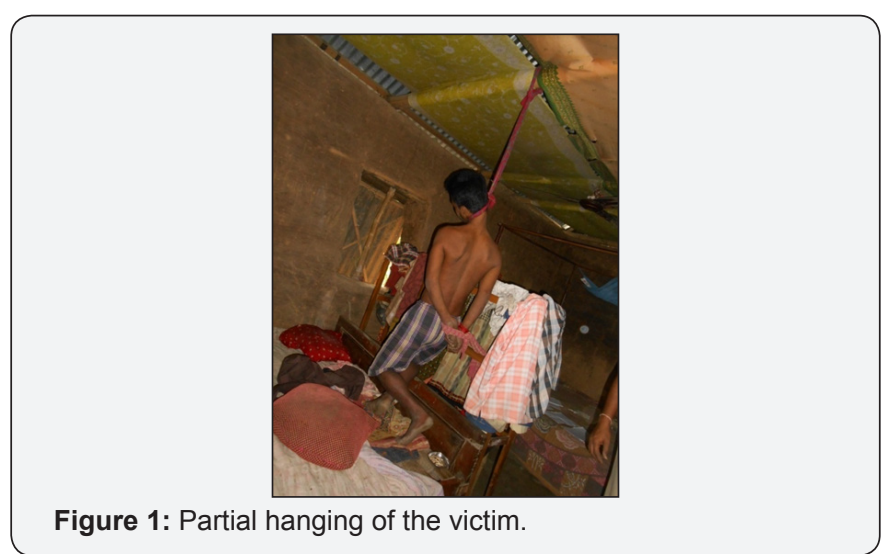


The profile of the criminal is unique and rare in this case shown in (Figures 1-4).
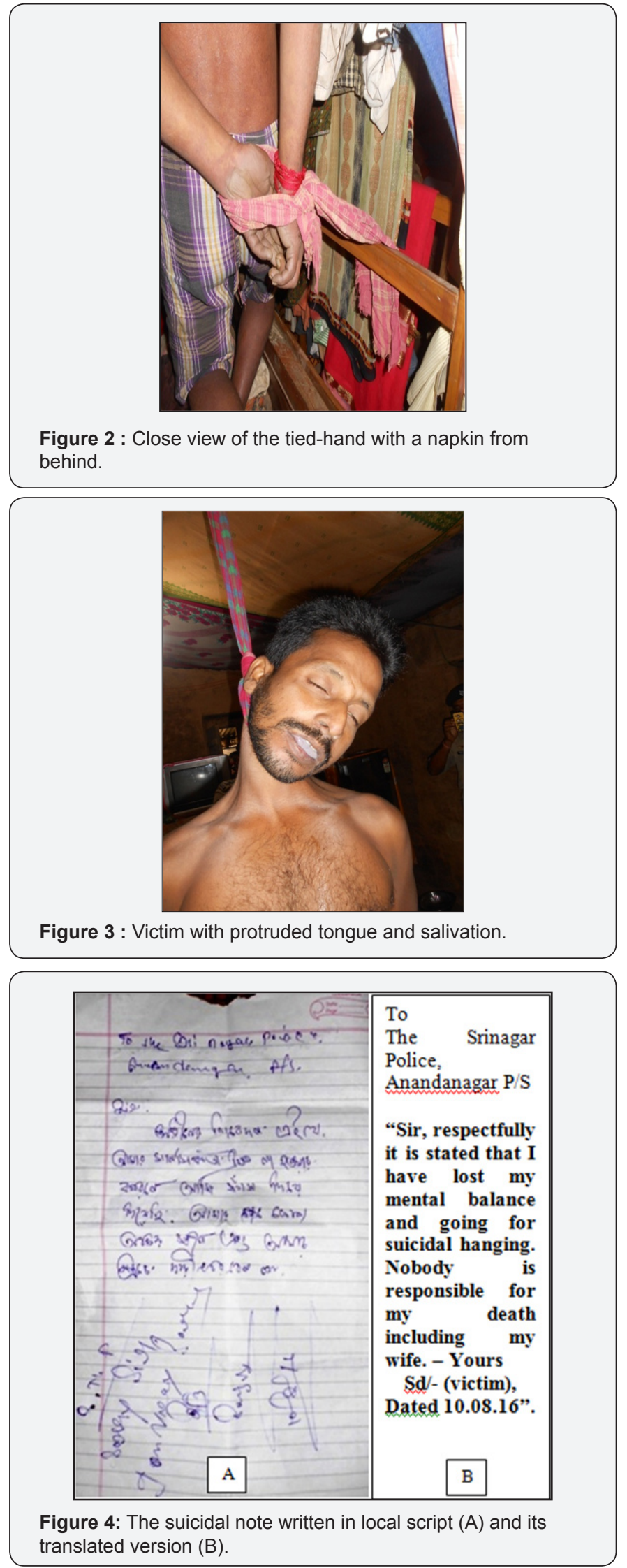

\section{Autopsy Findings}

\section{External}

The deceased was about 34 year old male, $149 \mathrm{~cm}$ in height, $57 \mathrm{~kg}$ in weight of average built. The eyes and mouth of the victim were partially open; tongue was caught between the teeth of both the jaws; dry saliva stain was present over the left side of anterior chest wall; both the hands were found loosely tied together by a napkin. One dark brown color parchment like non-continuous ligature mark having maximum width of $5 \mathrm{~cm}$ was obliquely present around the neck which was located $3 \mathrm{~cm}$ below the chin, $9 \mathrm{~cm}$ above the suprasternal notch, $6 \mathrm{~cm}$ below the tip of left mastoid process touching the tip of right mastoid process. The ligature mark was absent on the right back side of neck for a distance of $12 \mathrm{~cm}$.

\section{Internal}

The mucosa of the larynx was found congested; the trachea, bronchi and both the lungs were also found congested. On dissection, underlying skin and subcutaneous tissue were found pale and glistening. There was no extravasation of blood in the underlying neck structure. Thyroid cartilage, cricoids cartilage and hyoid bone were found intact. The toxicological analysis of viscera and body fluid ruled out the presence of poison and drug in this case. The cause of death was asphyxia as a result of hanging.

\section{Discussion}

The deceased hanged with tied-hands and feet touching the bed - a rare case of partial hanging. He also left a suicidal note in a local language addressed to the police. The investigation of undisturbed crime scene and hanging body with post mortem symptoms like ligature mark, protruded tongue, dribbling of saliva, involuntary discharge of semen, pale face, cyanosis on finger nails indicated the case to be suicidal hanging further supported by autopsy findings. The authorship of suicidal note along with above findings established the suicide beyond doubt. Further, such unusual hanging with tied hands committed to prevent self defense and premeditated to die could be the main reason of psychological profile of the victim.

\section{Acknowledgement}

The authors are thankful to Dr M S Rao, Ex-Chief Forensic Scientist, MHA, Government of India and Dr A Pal, Scientific Officer for their assistance.

\section{References}

1. National Crime Records Bureau (2015) Ministry of Home Affairs, Government of India.

2. Pal A, Pratihari HK (2017) Unusual Hanging- A Case report. J Forensic Cri Stu 1(102): 1-5.

3. Pal A, Pratihari HK (2018) Suicide Pact of a Love Couple - A Case report. J Forensic Sci \& Criminal Inves 7(2): 1-3.

4. Choudhury S, Pal A, Das RK, Pratihari HK (2017) Hanging of a Blind Man. J Forensic Sci \& Criminal Inves 4(4): 1-3. 
5. Sikari A K, Murty O P, Behera C, Rautji R (2016) Hand Tied With Bag Full of Books in Suicidal Hanging. J Forensic Sci 61(1): S265-S267.



This work is licensed under Creative Commons Attribution 4.0 License

DOI : 10.19080/JFSCI.2018.08.555732
6. https://www.theguardian.com/life and style/2010/apr/28/alexander-mcqueen-suicide-verdict-inquest.

Your next submission with Juniper Publishers will reach you the below assets

- Quality Editorial service

- Swift Peer Review

- Reprints availability

- E-prints Service

- Manuscript Podcast for convenient understanding

- Global attainment for your research

- Manuscript accessibility in different formats ( Pdf, E-pub, Full Text, Audio)

- Unceasing customer service

Track the below URL for one-step submission https://juniperpublishers.com/online-submission.php 